\title{
Blood Product Supply for a Helicopter Emergency Medical Service
}

\author{
Kathleen Selleng ${ }^{a} \quad$ Marcel Baschin $^{a}$ Berthold Henkel ${ }^{b}$ Gregor Jenichen ${ }^{b}$ \\ Karl-Christian Thies ${ }^{d, g}$ Marcus Rudolphd,e Florian Reifferscheid ${ }^{d, f}$ \\ Jörg Braun ${ }^{d}$ Malte Hannich $^{c}$ Theresa Winter ${ }^{c}$ Klaus Hahnenkamp ${ }^{b}$ \\ Andreas Greinacher ${ }^{\mathrm{a}}$ \\ anstitut für Immunologie und Transfusionsmedizin, Abteilung Transfusionsmedizin, Universitätsmedizin Greifswald,

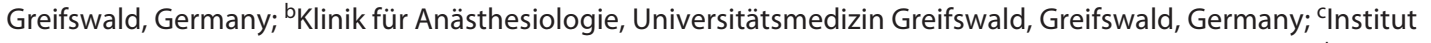 \\ für Klinische Chemie und Laboratoriumsmedizin, Universitätsmedizin Greifswald, Greifswald, Germany; ${ }^{\mathrm{d} D R F}$

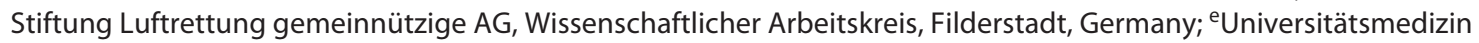

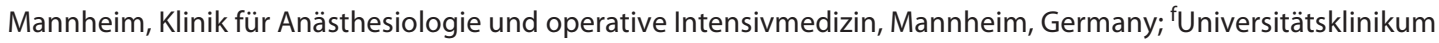 \\ Schleswig-Holstein, Campus Kiel, Klinik für Anästhesiologie und Operative Intensivmedizin, Kiel, Germany; \\ gUniversitätsklinik für Anästhesiologie, Intensiv-, Notfallmedizin, Transfusionsmedizin und Schmerztherapie, EvKB, \\ Universitätsklinikum OWL der Universität Bielefeld, Campus Bielefeld-Bethel, Bielefeld, Germany
}

\section{Keywords}

Transfusion therapy · Clotting factors · Thawed plasma · Helicopter emergency medical service

\begin{abstract}
Background: Long patient transport times to trauma centers are a well-known problem in sparsely populated regions with a low hospital density. Transfusion of red blood cell concentrates (RBC) and plasma improves outcome of trauma patients with severe bleeding. Helicopter emergency services (HEMS) are frequently employed to provide early advanced medical care and to reduce time to hospital admission. Supplying HEMS with blood products allows prehospital transfusion and may help to prevent exsanguination or prolonged hemorrhagic shock. We have investigated the maintenance of blood product quality under air transport conditions and the logistical steps to introduce a HEMS blood depot into routine practice. Methods: A risk analysis was performed and a validation plan developed. A special, commercially available transport container for blood products was identified. Maintenance of temperature conditions between 2 and $6^{\circ} \mathrm{C}$ in the box were monitored at ambient temperatures up to $35^{\circ} \mathrm{C}$ over $48 \mathrm{~h}$. Quality of blood products before and after helicopter air transport were evaluated including (1) for
\end{abstract}

\section{karger@karger.com} www.karger.com/tmh

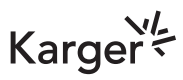

BOPEN ACCESS (c) 2021 The Author(s)

Published by S. Karger AG, Basel

This is an Open Access article licensed under the Creative Common Attribution-NonCommercial-4.0 International License (CC BY-NC) (http://www.karger.com/Services/OpenAccessLicense), applicable to the online version of the article only. Usage and distribution for commercial purposes requires written permission.
RBCs: hemoglobin, hematocrit, hemolysis rate; (2) for thawed plasma: aPTT, INR, single clotting factor activities. The logistics for blood supply of the regional HEMS were developed by the transfusion service of the Greifswald University Hospital in collaboration with the in-hospital transport team, the HEMS team, and the HEMS operator. Results: The transport container maintained a temperature below $6^{\circ} \mathrm{C}$ up to $36 \mathrm{~h}$ at $35^{\circ} \mathrm{C}$ ambient temperature. Vibration during helicopter operation did not impair quality of RBC and thawed plasma. To provide blood products for HEMS at least two transport containers and an additional set of cooling tiles is needed as the cooling tiles need a special temperature priming over $20 \mathrm{~h}$. The two boxes were used at alternate days. To reduce wastage, RBCs and thawed plasmas were exchanged every fourth day and reintegrated into the blood bank inventory for further in-hospital use. Conclusions: Supplying HEMS with RBCs and plasma is feasible. Helicopter transport has no negative impact on blood product quality. The logistic challenges require close collaboration between the HEMS team and the blood transfusion service.

(c) 2021 The Author(s). Published by S. Karger AG, Basel

The first two authors contributed equally to this work. 


\section{Introduction}

Bleeding is one of the leading causes of early death in trauma patients [1-3]. In a prospective multicenter cohort study of trauma medical care (PROMMTT) including more than 900 patients $94 \%$ of hemorrhagic deaths occurred within $24 \mathrm{~h}$, the majority of these deaths (60\%) occurred within $3 \mathrm{~h}$ of admission, and the median time to hemorrhagic death was $2.6 \mathrm{~h}$ (interquartile range, 1.7-5.4 h) [4]. A transfusion ratio of plasma: $R B C \geq 1: 2$ during the first $6 \mathrm{~h}$ after arrival at the emergency department (minute 31 to hour 6) was associated with reduced mortality (HR 0.31, 0.16-0.58) [4]. Pre-hospital transfusion can bridge time until hospital admission. The flight time of the helicopter from the scene to the hospital is usually relatively short. Prehospital transfusion is especially relevant if the patient cannot be immediately transported from the scene (e.g., entrapped in a car wreck). Helicopter emergency services (HEMS) and prehospital transfusions can improve the outcome of patients $[5,6]$. Recent data also indicate that prehospital transfusion is safe [7-14]. However, it may introduce additional risks for adverse outcomes like induction of hypothermia by non-prewarmed blood [15]. Therefore, it is still under debate whether it improves short-term or long-term survival in civilian settings. The different blood products used by the different rescue services further complicate interpretation and generalization of available data.

In any case, the supply of HEMS with blood products is challenging: a) space and weight limits, no electricity supply on the helicopter; b) influence of vibrations, flight conditions by the helicopter depending on helicopter model [16]; c) variable storage conditions for different blood products; d) variable expiration times of different blood products; e) requests for transfusion safety based on national guidelines for hemotherapy [17].

The implementation of prehospital blood supply for HEMS, locally established for the helicopter Christoph 47 (DRF Stiftung Luftrettung gAG), by the department of transfusion medicine of the University Medicine Greifswald (UMG) is described including risk analysis, validation of the blood product quality, and process organization.

\section{Material and Methods}

\section{Definition of Requirements}

As first step the requirements for providing blood products on the helicopter were defined and related risks identified. Requirements were defined by discussion between transfusion medicine staff and the HEMS team of the Department of Anaesthesiology of the UMG together with the HEMS operator. Discussions were performed in formal meetings either in person or via videoconference. The following items were identified:
1 The blood product transport container should be able to store 4-6 blood bags (RBCs and plasma) and maintain temperatures between 2 and $6^{\circ} \mathrm{C}, \max .10^{\circ} \mathrm{C}$ for at least $12 \mathrm{~h}$. The time period of $12 \mathrm{~h}$ was necessary because the shift of the helicopter rescue team is $12 \mathrm{~h}$ long and an exchange of blood products is only feasible when the shift team is changing.

2 The blood product inventory should be able to accommodate thawed plasma $\left(2-6^{\circ} \mathrm{C}\right)$ or lyophilized plasma $(200 \mathrm{~mL}$ glass flasks).

3 Air transport should not impair the quality of the blood products, as defined by the national hemotherapy guidelines.

4 Blood product quality should allow re-integration of non-used blood products into the regular stock of the blood bank to avoid unnecessary wastage.

\section{Risk Analysis}

A risk analysis was performed following the EU-GMP guidelines. A risk priority number (RPN) was calculated based on the Failure Mode and Effects Analysis (FMEA) method [18, 19]. Therefore, the probability of failure occurrence and failure detection was evaluated and the product (RPN) of both calculated (Table 1). An RPN >12 was defined as threshold, which requires validation of the process (Table 1) [20]. As key critical points we identified:

- maintenance of storage temperature between 2 and $6^{\circ} \mathrm{C}$ for at least $12 \mathrm{~h}$ preferentially with additional time buffer

- maintenance of quality of RBC and thawed plasma according to the German hemotherapy guidelines [17].

\section{Validation Plan}

As storage container the Credo Cube ${ }^{\mathrm{TM}}$ (PELICAN BioThermalTM, Plymouth, USA) was identified. The inner wall of this box is covered by 6 special cooling tiles. Before use, these tiles are prepared as follows: storage at $<-18^{\circ} \mathrm{C}$ for $12 \mathrm{~h}$, followed by storage at $2-6^{\circ} \mathrm{C}$ for $8 \mathrm{~h}$. After this initial temperature priming step the cooling tiles can be stored at $2-6^{\circ} \mathrm{C}$ for at least 7 days and are ready to use in the Credo Cube ${ }^{\mathrm{TM}}$, according to the manufacturer, without electricity.

The temperature was monitored by temperature loggers (elpro, Buchs, Switzerland and TUTELA monitoring systems, Fleet, UK). After temperature priming of the cooling tiles (as described above) the empty Credo Cube ${ }^{\mathrm{TM}}$ was stored for $48 \mathrm{~h}$ at room temperature and at $35^{\circ} \mathrm{C}$, respectively. Temperature was continuously recorded and analyzed by software (elproLOG analyze, Buchs, Switzerland).

\section{Validation of the Blood Product Quality}

Quality measurements of blood products were performed before and after transport of the blood products on the helicopter to assess any impact of flight related vibration, acceleration, etc. on product quality.

Samples from the blood bags were drawn by sterile docking before air transport (baseline) and $24 \mathrm{~h}$ after the baseline sample was taken (1 day HEMS operation). To test if the blood products can be used for several days, the same blood products were on the helicopter at day 1 , day 3 , and day 5 (Table 2). Between each operation day the blood products were stored at $4^{\circ} \mathrm{C}$ in the blood bank. During this time the cooling tiles were re-primed. This evaluation should allow using blood products over 3 days on the helicopter (3 days HEMS operation).

\section{Quality Assessment of RBCs}

Hemoglobin concentration and hematocrit were measured by automated cell counter (XN-9000, Sysmex, Norderstedt, Germany). The hemolysis rate was measured by UV spectrophotometer (UV-1700 PharmaSec, Shimadzu Corporation, Kyoto, Japan). Potassium concentration and lactate dehydrogenase levels were mea- 
Table 1. Risk analysis to recognize significant processes, which has to be validated following FMEA-criteria (factor $1=$ low risk, $5=$ high risk)

Risk

$\begin{array}{llll}\begin{array}{l}\text { Probability of Severity } \\ \text { failure } \\ \text { occurrence }\end{array} & \begin{array}{l}\text { Probability } \\ \text { of discovery }\end{array} & \text { RPN } \\ 2 & 5 & 3 & 30 \\ 3 & 5 & 2 & 30 \\ 4 & 5 & 4 & 80 \\ 4 & 5 & 4 & 80 \\ 3 & 5 & 1 & 15 \\ 3 & 5 & 1 & 15 \\ 2 & 5 & 1 & 10\end{array}$

Transport container is not sufficiently pre-cooled

Temperature increases $>6^{\circ} \mathrm{C}$ during transport

Hemolysis of RBCs

Clotting factor activity decrease $<50 \%$

Patient blood is not drawn, post-transfusion compatibility testing in the laboratory after admission of the patient to hospital is not possible

Transfusion documents are not returned by the helicopter team to the transfusion medicine laboratory, patient and/or product lookback is not possible

Non-authorized access to blood products

A risk priority number $>12$ is the criterion for initiating a validation process.

Table 2. Validation plan for short-term and long-term evaluation of blood product quality over 3 HEMS operation days

\begin{tabular}{|c|c|c|c|c|c|c|c|}
\hline Day 1 & & Day 2 & & Day 3 & Day 4 & Day 5 & \\
\hline $\begin{array}{l}\text { Baseline sample } \\
\text { was taken from } \\
\text { the blood products }\end{array}$ & $\begin{array}{l}\text { HEMS in operation, } \\
\text { blood products } \\
\text { were transported }\end{array}$ & $\begin{array}{l}\text { One-day-operation } \\
\text { sample was taken } \\
\text { from the blood } \\
\text { products }\end{array}$ & $\begin{array}{l}\text { No operation day, blood } \\
\text { products stored in the } \\
\text { blood bank inventory, } \\
\text { re-priming of cooling tiles }\end{array}$ & $\begin{array}{l}\text { HEMS in operation, } \\
\text { blood products } \\
\text { were transported }\end{array}$ & $\begin{array}{l}\text { No operation day, blood } \\
\text { products stored in the } \\
\text { blood bank inventory, } \\
\text { re-priming of cooling tiles }\end{array}$ & $\begin{array}{l}\text { HEMS in operation, } \\
\text { blood products } \\
\text { were transported }\end{array}$ & $\begin{array}{l}\text { 3-day-operation } \\
\text { sample was } \\
\text { taken from the } \\
\text { blood products }\end{array}$ \\
\hline
\end{tabular}

sured by automated system (Dimension Vista ${ }^{\circledR} 1500$ System; Siemens Healthineers, Eschborn, Germany).

Quality Assessment of Thawed Plasma (tFFP)

a) Evaluation of the impact of 1 day HEMS operation: tFFP quality parameters were measured at baseline and $24 \mathrm{~h}$ after baseline. b) Evaluation of the impact of 3 days HEMS operation: tFFP bags were divided into two identical units. One unit was stored at $4^{\circ} \mathrm{C}$ in the blood bank (control unit) and the second was used on the helicopter (air transport units). Samples were drawn and stored at $\leq-30^{\circ} \mathrm{C}$ until measurement (Table 2). For plasma quality assessment global hemostasis parameters prothrombin time (Quick/ INR; Dade ${ }^{\circledR}$ Innovin $^{\circledR}$, SIEMENS Healthcare Diagnostics Products $\mathrm{GmbH}$, Marburg, Germany) and the activated partial thromboplastin time (aPTT; Dade ${ }^{\circledR}$ Actin ${ }^{\circledR}$ FS Activated PTT Reagent, SIEMENS Healthcare Diagnostics Products GmbH, Marburg, Germany) were measured. Further, single clotting factor activities were measured (Table 3).

\section{Development of Logistics for HEMS Blood Supply}

To establish the logistics for blood supply several meetings between the HEMS team, in-hospital transport service, the staff of the in-hospital emergency department - as handover point between in-hospital transport team and HEMS team - and the blood bank were performed. The introduction of HEMS blood supply was a stepwise process with continuous monitoring and adjustments if needed. The blood bank team organized the preparation of the Credo Cube ${ }^{\mathrm{TM}}$, the logistics of blood product exchange and temperature monitoring. The HEMS team organized the Credo $\mathrm{Cube}^{\mathrm{TM}}$ transport between blood bank and helicopter port considering the HEMS working shifts. Medical staff of HEMS were edu- cated for the special conditions of pretransfusional hemotherapy. At the beginning of HEMS blood supply the helicopter worked between sunrise and sunset and was later adopted to a 2-shift/24-h operation.

\section{Results}

Temperature Maintenance of the Transport Container

The low-temperature primed $\left(\leq-18^{\circ} \mathrm{C}\right)$ Credo Cube $\mathrm{CM}^{\mathrm{TM}}$ maintained the temperature of $2-6^{\circ} \mathrm{C}$ for at least $48 \mathrm{~h}$ if surrounding temperature was below $24^{\circ} \mathrm{C}$, for higher temperatures up to $35^{\circ} \mathrm{C}$ the inner temperature could be maintained up to $36 \mathrm{~h}$ below $6^{\circ} \mathrm{C}(n=3$ each) (shown in Fig. 1). After priming of the cooling tiles at $4^{\circ} \mathrm{C}$ (skipping the $-18^{\circ} \mathrm{C}$ incubation step) the inner temperature of the box crossed the limit of $6^{\circ} \mathrm{C}$ after $5 \mathrm{~h}$.

\section{Quality Assessment of RBCs}

During 1 day HEMS operation (short-term evaluation of the blood product quality) the median helicopter-inoperation time (the helicopter rotor is working) was 219 min per day (range 172-255 min) including 10-12 start and landing procedures per day. During the 3 days HEMS operation cumulative helicopter-in-operation time was $521 \mathrm{~min}$ with a median of $181 \mathrm{~min}$ per day (range 111-229 min) including 24 start and landing procedures. 
Table 3. Single clotting factor activities and their respective reagent are listed

\begin{tabular}{ll}
\hline Clotting factor & Analysis by \\
\hline Fibrinogen & Dade Innovin, SIEMENS Healthcare, Marburg, Germany \\
Factor II, V, VII, VIII, IX, XII, XIII & Actin FSL, SIEMENS Healthcare, Marburg, Germany \\
Protein S & Hemoclot Protein S, Coachrom (Hyphen Biomed), Austria \\
Protein C & Protein C reagent, SIEMENS Healthcare, Marburg, Germany \\
Von Willebrand factor antigen & WF-Ag, SIEMENS Healthcare, Marburg, Germany \\
Von Willebrand factor activity & Innovance WF-AC, SIEMENS Healthcare, Marburg, Germany \\
\hline
\end{tabular}

All analyses were performed on the CS-5100 (Sysmex).

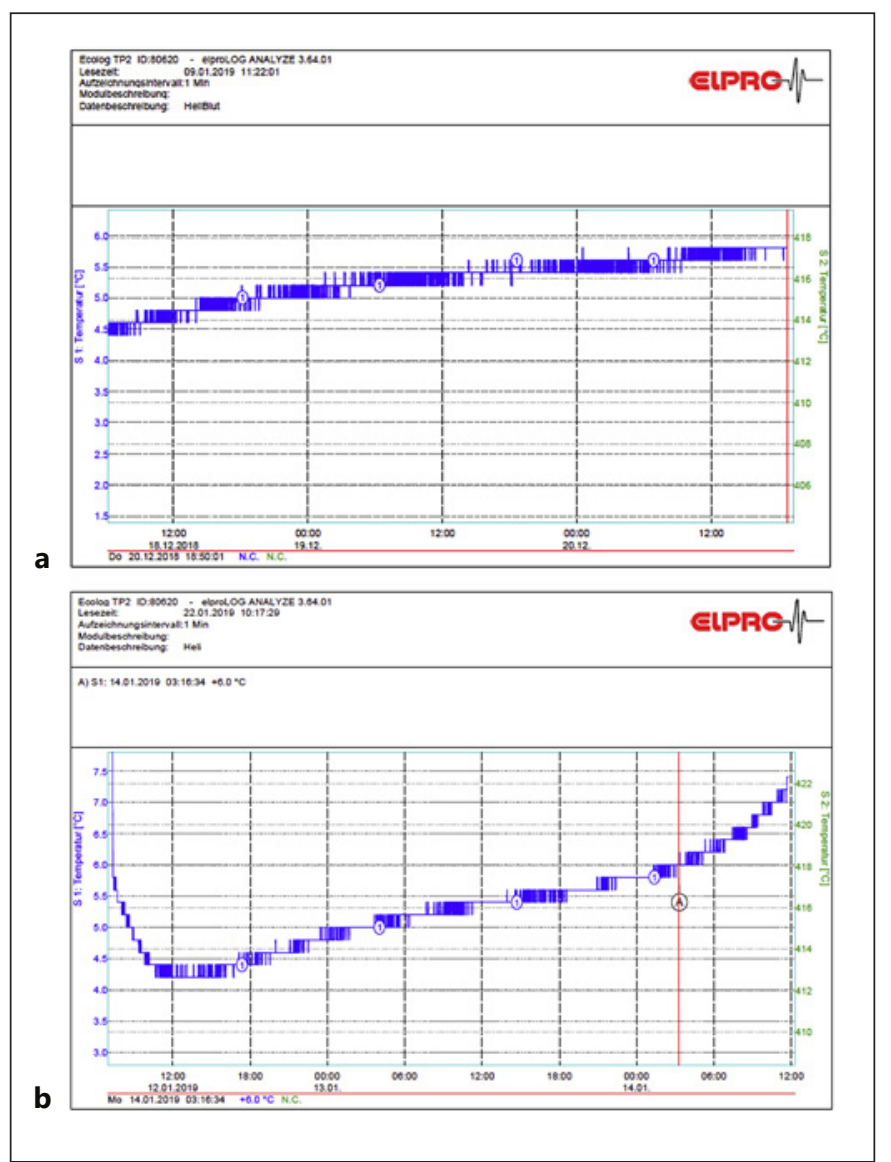

Fig. 1. Reports of temperature monitoring recorded by temperature logger in the empty Credo Cube ${ }^{\mathrm{TM}}$ stored at surrounding temperature $20-24^{\circ} \mathrm{C}(\mathbf{a})$ and at $35^{\circ} \mathrm{C}$ (b) for more than $48 \mathrm{~h}$. Temperatures up to $35^{\circ} \mathrm{C}$ limited the working time of the Credo Cube ${ }^{\mathrm{TM}}$ with inner temperature condition $<6^{\circ} \mathrm{C}$ to a maximum of $40 \mathrm{~h}$ (red line indicates the time when the inner temperature of the box exceeded $\left.6^{\circ} \mathrm{C}\right)$.

The Credo Cube ${ }^{\mathrm{TM}}$ was loaded with three RBCs and three tFFP. For 1 day HEMS operation 12 RBCs were assessed. For 3 days HEMS operation 3 RBCs were assessed over 5 days as described in Table 2. After return to the blood bank no signs of hemolysis were observed. Hemo- globin concentration and hematocrit did not deviate from the requested specifications (Tables 4, 5) [17]. Potassium levels slightly increased but did not exceed the limit of $60 \mathrm{mmol} / \mathrm{L}$ (approved by the drug authority for RBCs of our institution; Human-Erythrozytenkonzentrat PAGGSM, leukozytendepletiert/HGW) (Tables 4, 5).

\section{Quality Assessment of tFFP}

For 1 day HEMS operation 12 tFFPs were assessed. For 3 days HEMS operation 3 tFFPs were assessed and compared with their biologically identical split units stored at $4^{\circ} \mathrm{C}$ in the blood bank. Four of the FFPs already showed decreased clotting factor activities $<50 \%$ immediately after thawing: FVII activity of $41 \%$ and $46 \%$, FVIII activity of $44 \%$, and FXII activity of $<5 \%$ (this tFFP was excluded from the analysis of FXII). After short-term HEMS operation clotting factor VIII showed the most pronounced decrease during $24 \mathrm{~h}$ after thawing (by median 13\%). All other clotting factors decreased by less than $5 \%$ (Table 6). After 3 days HEMS operation the decrease of clotting factors in the air transport units was comparable to the control units stored in the blood bank. In tFFPs most pronounced decrease in clotting factor activity was observed for clotting factor VIII (by mean $37 \%$, final levels $36-57 \%$ ), protein S (by mean $24 \%$, final levels $55-103 \%$ ), and clotting factor XI (mean $11 \%$, final levels $89-119 \%$ ). The changes of global coagulation parameters PT (Quick) and aPTT, and single clotting factors fibrinogen, factors II, V, VII, IX, X, XII, XIII, vWF-Ag and -activity, and Protein C were less than $10 \%$ after 3 flight days. The changes of all coagulation parameters of the tFFP air transport units were in the same range as in the respective control units stored in the blood bank at $4^{\circ} \mathrm{C}$ : clotting factor VIII (by mean $39 \%$, final levels $36-61 \%$ ), protein S (by mean $19 \%$, final levels 60-97\%), and clotting factor XI (by mean $11 \%$, final levels 96-129\%) (Table 7). The only exception was seen for factor $\mathrm{V}$ where the decrease in the air transport units was slightly larger than in the control units $(-7.3 \%$ vs. $-1.7 \%$; Table 7 ). 
Table 4. RBC quality measurements before/after 1 day HEMS operation (mean, range; $n=12$ )

\begin{tabular}{lllll}
\hline & Baseline & 24 h after baseline & Specification & $\begin{array}{l}\Delta \text { before and after 1 day } \\
\text { HEMS operation }\end{array}$ \\
\hline $\mathrm{Hb} /$ unit, $\mathrm{g}$ & $45.35(35.6-53.8)$ & $46.29(36.3-55.8)$ & $\geq 40.0$ & 0.94 \\
$\mathrm{HK}, \mathrm{L} / \mathrm{L}$ & $0.522(0.465-0.561)$ & $0.531(0.494-0.567)$ & $0.50-0.70$ & 0.010 \\
Rate of hemolysis, \% & $0.282(0.176-0.495)$ & $0.261(0.171-0.450)$ & $<0.8$ & -0.021 \\
Potassium, mmol/L & $16.10(9.50-30.10)$ & $18.04(11.60-31.50)$ & $<60$ & 1.94 \\
\hline
\end{tabular}

Table 5. RBC quality measurements before/after 3 days HEMS operation (mean, range; $n=3$ )

\begin{tabular}{lllll}
\hline & Baseline & $\begin{array}{l}\text { After 3 days HEMS } \\
\text { operation (day 5 after } \\
\text { baseline) }\end{array}$ & Specification & $\begin{array}{l}\Delta \text { before and after } 3 \\
\text { transport days }\end{array}$ \\
\hline Hb/unit, g & $45.8(44.3-8.1)$ & $49.5(45.0-53.0)$ & $\geq 40.0$ & 3.7 \\
HK, L/L & $0.51(0.46-0.54)$ & $0.55(0.54-0.57)$ & $0.50-0.70$ & 0.041 \\
Hemolysis rate, \% & $0.32(0.23-0.45)$ & $0.21(0.15-0.27)$ & $<0.8$ & -0.102 \\
Potassium, mmol/L & $12.4(9.5-15.9)$ & $20.8(17.0-25.8)$ & $<60$ & 8.5 \\
\hline
\end{tabular}

$\mathrm{Hb}$, hemoglobin; HK, hematocrit.

Table 6. tFFP quality measurements before/after 1 day HEMS operation (mean, range; $n=12$ ); decrease of activity $>10 \%$ is marked in grey

\begin{tabular}{llll}
\hline & Baseline & $\begin{array}{l}24 \mathrm{~h} \text { after baseline, } \\
\text { 1 day HEMS operation }\end{array}$ & $\begin{array}{l}\Delta \text { before and } \\
\text { after transport }\end{array}$ \\
\hline Prothrombin time, \% & $77.0(59.0-103.0)$ & $75.4(58.0-101.0)$ & -1.6 \\
Activated partial prothrombin time, s & $29.0(23.0-34.0)$ & $29.9(24.0-36.0)$ & 0.9 \\
Fibrinogen, g/L & $2.3(1.6-3.4)$ & $2.4(1.7-3.3)$ & 0.1 \\
Factor II, \% & $92.7(76.0-134.0)$ & $92.3(76.0-136.0)$ & -0.3 \\
Factor V, \% & $81.8(54.0-114.0)$ & $78.8(50.0-111.0)$ & -3.0 \\
Factor VII, \% & $76.3(46.0-108.0)$ & $76.7(41.0-140.0)$ & 0.3 \\
Factor VIII, \% & $81.6(44.0-116.9)$ & $68.8(33.7-92.2)$ & -12.8 \\
Factor IX,\% & $90.3(72.0-118.0)$ & $89.6(73.0-128.0)$ & -0.7 \\
Factor X,\% & $96.9(79.0-114.0)$ & $99.3(72.0-131.0)$ & 2.3 \\
Factor XI, \% & $89.8(66.0-136.0)$ & $87.8(62.0-138.0)$ & -2.1 \\
Factor XII, \% & $77.9(41.0-112.0)$ & $78.9(41.0-118.0)$ & 1.0 \\
Factor XIII, \% & $101.8(71.0-143.0)$ & $103.0(68.0-143.0)$ & 1.2 \\
Von Willebrand factor antigen, \% & $106.3(62.0-164.0)$ & $106.1(57.0-163.0)$ & -0.2 \\
Von Willebrand factor activity, \% & $95.1(52.0-158.0)$ & $94.3(47.0-154.0)$ & -0.8 \\
Protein C, \% & $93.9(75.0-115.0)$ & $95.9(76.0-119.0)$ & 2.0 \\
Protein S, \% & $91.6(55.0-121.0)$ & $87.7(47.0-123.0)$ & -3.9 \\
\hline
\end{tabular}

\section{Logistic Process for Providing Blood Products for HEMS}

The final logistical process has been established: two transport containers and three sets of cooling tiles are in use. While one Credo Cube ${ }^{\mathrm{TM}}$ is on the helicopter, the second with cooling tiles is reactivated. A third set of cooling tiles is stored at $2-6^{\circ} \mathrm{C}$ as backup system.
The Credo Cube ${ }^{\mathrm{TM}}$ is loaded by the blood bank staff with three tFFPs blood type $\mathrm{AB}$ or $\mathrm{A}$ (in case of $\mathrm{AB}$ shortage) and three RBCs of blood type $\mathrm{O}$ Rh positive or two lyophilized plasmas (Lyoplas ${ }^{\circledR}$, DRK Blutspendedienst West) and two RBCs and issued in the morning (shown in Fig. 2a, b). To avoid shortage of AB plasma, we also use blood type A plasma for the Credo Cube ${ }^{\mathrm{TM}}$ as it was shown 
Table 7. $\operatorname{tFFP}$ quality measurements of split tFFP $(n=3)$ before/after 3 days HEMS operation (air transport) or storage in parallel in the blood bank at $2-6^{\circ} \mathrm{C}$ (control, $n=3$ ) (mean, range); decrease of activity $>10 \%$ is marked in grey

\begin{tabular}{|c|c|c|c|c|}
\hline Parameter & $\begin{array}{l}\text { Air transport units/ } \\
\text { control units }\end{array}$ & Baseline & $\begin{array}{l}\text { After } 3 \text { days HEMS operation } \\
\text { ( } 5 \text { days after baseline) }\end{array}$ & $\begin{array}{l}\Delta \text { before and after } \\
3 \text { transport days }\end{array}$ \\
\hline Quick, \% & $\begin{array}{l}\text { Air transport } \\
\text { Control }\end{array}$ & $\begin{array}{l}81.3(63.0-103.0) \\
85.7(68.0-107.0)\end{array}$ & $\begin{array}{l}74.3(59.0-89.0) \\
78.0(63.0-95.0)\end{array}$ & $\begin{array}{l}-7.0 \\
-7.7\end{array}$ \\
\hline aPTT, s & $\begin{array}{l}\text { Air transport } \\
\text { Control }\end{array}$ & $\begin{array}{l}24.7(23.0-27.0) \\
23.7(22.0-26.0)\end{array}$ & $\begin{array}{l}27.7(25.0-31.0) \\
26.7(25.0-29.0)\end{array}$ & $\begin{array}{l}3.0 \\
3.0\end{array}$ \\
\hline Fibrinogen, $\mathrm{g} / \mathrm{L}$ & $\begin{array}{l}\text { Air transport } \\
\text { Control }\end{array}$ & $\begin{array}{l}2.2(1.8-3.0) \\
2.4(2.0-3.3)\end{array}$ & $\begin{array}{l}2.2(1.8-2.9) \\
2.4(1.9-3.2)\end{array}$ & $\begin{array}{l}0.0 \\
-0.1\end{array}$ \\
\hline Factor II, \% & $\begin{array}{l}\text { Air transport } \\
\text { Control }\end{array}$ & $\begin{array}{l}112.0(95.0-134.0) \\
122.3(102.0-140.0)\end{array}$ & $\begin{array}{l}110.0(90.0-136.0) \\
121.7(104.0-140.0)\end{array}$ & $\begin{array}{l}-2.0 \\
-0.7\end{array}$ \\
\hline Factor $\mathrm{V}, \%$ & $\begin{array}{l}\text { Air transport } \\
\text { Control }\end{array}$ & $\begin{array}{l}99.3(80.0-114.0) \\
102.3(75.0-123.0)\end{array}$ & $\begin{array}{l}92.0(74.0-101.0) \\
100.7(74.0-117.0)\end{array}$ & $\begin{array}{l}-7.3 \\
-1.7 \\
\end{array}$ \\
\hline Factor VII, \% & $\begin{array}{l}\text { Air transport } \\
\text { Control }\end{array}$ & $\begin{array}{l}65.0(46.0-88.0) \\
70.3(45.0-101.0)\end{array}$ & $\begin{array}{l}56.7(40.0-74.0) \\
63.7(43.0-85.0)\end{array}$ & $\begin{array}{l}-8.3 \\
-6.7\end{array}$ \\
\hline Factor VIII, \% & $\begin{array}{l}\text { Air transport } \\
\text { Control }\end{array}$ & $\begin{array}{l}84.3(64.2-97.8) \\
89.9(65.3-107.7)\end{array}$ & $\begin{array}{l}47.3(36.1-56.7) \\
51.1(35.7-61.3)\end{array}$ & $\begin{array}{l}-37.0 \\
-38.8\end{array}$ \\
\hline Factor IX, \% & $\begin{array}{l}\text { Air transport } \\
\text { Control }\end{array}$ & $\begin{array}{l}94.7(91.0-100.0) \\
106.0(104.0-109.0)\end{array}$ & $\begin{array}{l}91.7(88.0-98.0) \\
102.0(99.0-108.0)\end{array}$ & $\begin{array}{l}-3.0 \\
-4.0\end{array}$ \\
\hline Factor $\mathrm{X}, \%$ & $\begin{array}{l}\text { Air transport } \\
\text { Control }\end{array}$ & $\begin{array}{l}101.7(79.0-114.0) \\
115.7(85.0-133.0)\end{array}$ & $\begin{array}{l}100.0(72.0-120.0) \\
116.3(87.0-133.0)\end{array}$ & $\begin{array}{l}-1.7 \\
-0.7\end{array}$ \\
\hline Factor XI, \% & $\begin{array}{l}\text { Air transport } \\
\text { Control }\end{array}$ & $\begin{array}{l}112.0(94.0-136.0) \\
121.0(104.0-146.0)\end{array}$ & $\begin{array}{l}100.7(89.0-119.0) \\
109.7(96.0-129.0)\end{array}$ & $\begin{array}{l}-11.3 \\
-11.3\end{array}$ \\
\hline Factor XII, \% & $\begin{array}{l}\text { Air transport } \\
\text { Control }\end{array}$ & $\begin{array}{l}89.0(73.0-112.0) \\
98.7(81.0-122.0)\end{array}$ & $\begin{array}{l}92.7(75.0-119.0) \\
99.0(82.0-121.0)\end{array}$ & $\begin{array}{l}3.7 \\
0.3\end{array}$ \\
\hline Factor XIII, \% & $\begin{array}{l}\text { Air transport } \\
\text { Control }\end{array}$ & $\begin{array}{l}114.0(103.0-123.0) \\
118.3(108.0-130.0)\end{array}$ & $\begin{array}{l}116.3(103.0-126.0) \\
118.3(109.0-127.0)\end{array}$ & $\begin{array}{l}2.3 \\
0.0\end{array}$ \\
\hline vWF antigen, \% & $\begin{array}{l}\text { Air transport } \\
\text { Control }\end{array}$ & $\begin{array}{l}85.7(74.0-92.0) \\
81.3(68.0-89.0)\end{array}$ & $\begin{array}{l}85.3(81.0-89.0) \\
82.7(74.0-87.0)\end{array}$ & $\begin{array}{l}-0.3 \\
1.3\end{array}$ \\
\hline vWF activity, \% & $\begin{array}{l}\text { Air transport } \\
\text { Control }\end{array}$ & $\begin{array}{l}96.3(76.0-115.0) \\
70.0(67.0-75.0)\end{array}$ & $\begin{array}{l}68.0(60.0-75.0) \\
67.0(64.0-72.0)\end{array}$ & $\begin{array}{l}-4.0 \\
-3.0\end{array}$ \\
\hline Protein C, \% & $\begin{array}{l}\text { Air transport } \\
\text { Control }\end{array}$ & $\begin{array}{l}96.3(76.0-115.0) \\
97.7(76.0-117.0)\end{array}$ & $\begin{array}{l}103.3(83.0-122.0) \\
102.3(82.0-121.0)\end{array}$ & $\begin{array}{l}7.0 \\
4.7\end{array}$ \\
\hline Protein S, \% & $\begin{array}{l}\text { Air transport } \\
\text { Control }\end{array}$ & $\begin{array}{l}103.0(76.0-121.0) \\
98.3(78.0-109.0)\end{array}$ & $\begin{array}{l}79.0(55.0-103.0) \\
79.0(60.0-97.0)\end{array}$ & $\begin{array}{l}-24.0 \\
-19.3\end{array}$ \\
\hline
\end{tabular}

that low volumes of blood type A plasma are not harmful in emergency transfusion of a patient of unknown blood type $[21,22]$. In case of transfusion no more than three units of $\mathrm{AB} 0$ incompatible plasma would be transfused. In addition, empty blood tubes for blood drawing before transfusion, needed for subsequent blood group typing after hospital admission, a transfusion protocol, and two bedside AB0 typing cards (Medtro ${ }^{\circledR}$, Medtro, Bammental, Germany) are included into the box (shown in Fig. 2a). If Lyoplas is provided, the box contains additionally two reconstitution fluid bags and two transfer sets (shown in Fig. $2 b$ ). This reduces the space and allows to transport two RBC units only. We provide all documentary material in the same box as the blood products to reduce the risk of missing documentation.

Two cooling containers are used in the routine on alternate days. The Credo Cube ${ }^{\mathrm{TM}}$ is issued early in the morning before the day HEMS shift starts. It is carried to the in-hospital emergency department by the in-hospital transport team and is picked up there by the helicopter team at the beginning of the day shift. The Credo Cube ${ }^{\mathrm{TM}}$ is placed into the helicopter (shown in Fig. 2c) together with a blood warming device (Quinflow Warrior lite ${ }^{\mathrm{TM}}$ ). When the night shift is finished ( $24 \mathrm{~h}$ later), the Credo 


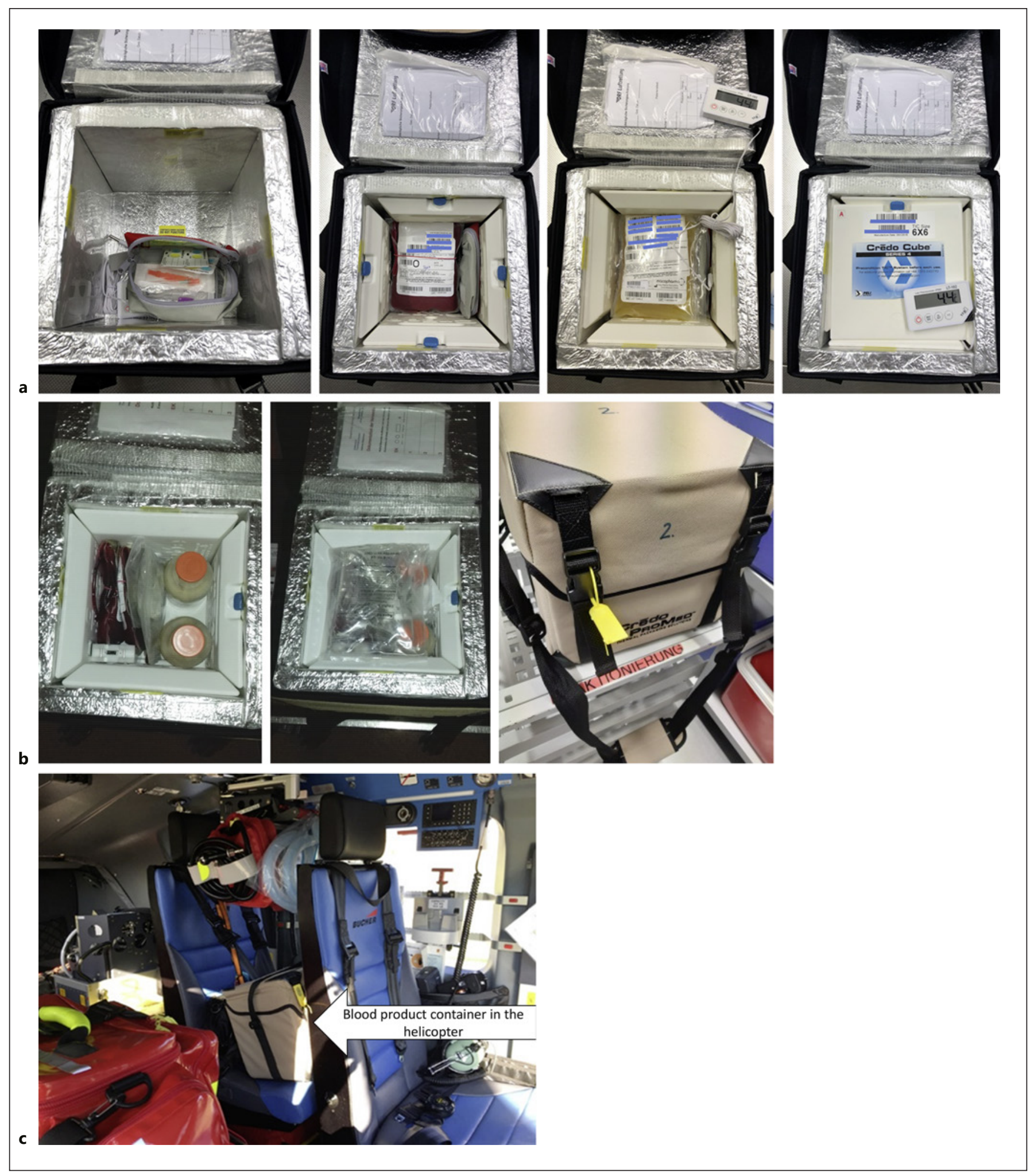

Fig. 2. Packing of the Credo Cube ${ }^{\mathrm{TM}}$ : a small bag with bedside $\mathrm{ABO}$ typing cards, blood drawing material, a minmax thermometer, 3 RBC and 3 tFFP units (a) or alternatively 2 RBC units and two bottles of lyophilized plasma (b), two bags of reconstitution fluid for the lyophilized plasma, and two transfer sets. A transfusion protocol and 5 patient identifier bracelets are placed at the inner side of the cover. For air transport the Credo Cube ${ }^{\mathrm{TM}}$ is tied to a helicopter seat $(\mathbf{c})$. 
Cube ${ }^{\mathrm{TM}}$ is returned to the blood bank. After return the logger records are checked. If temperature is maintained below $6^{\circ} \mathrm{C}$, the blood products are stored in the blood bank for 1 day and are used again for the next HEMS operation day. After 3 days, new RBCs and tFFPs are issued with the Credo Cube ${ }^{\mathrm{TM}}$. The RBCs and tFFPs from the previous transport days are visibly checked for hemolysis or abnormalities and returned into the blood bank inventory until their expiration (RBCs 49 days, tFFP 7 days after thawing at $2-6^{\circ} \mathrm{C}$ in the thawed plasma bank) [23].

In case of transfusion, a pretransfusion blood sample is drawn and the transfusion protocol is filled in. Patient blood samples, the transfused empty blood bags, and the transfusion protocol are returned to the blood bank. In the blood bank tube segments of the RBCs issued in the Credo box are stored in the fridge and are used for retrospective compatibility testing. Data on the transfusion protocol are stored for lookback events. The empty Credo $\mathrm{Cube}^{\mathrm{TM}}$ is newly packed using the backup cooling tiles and new blood products and returned to the helicopter.

To prevent unauthorized opening, the Credo Cube ${ }^{\mathrm{TM}}$ is sealed and the seal must be broken before the box can be opened (shown in Fig. 2b, right picture).

\section{Legal Requirements}

The hospital transfusion service is a different legal entity than the HEMS operator. Both institutions have to establish their own quality management system according to the local requirements. In Germany these are defined by the transfusion law and the hemotherapy guidelines $[17,24]$. To be able to re-integrate the blood products into the blood bank inventory, we have defined the sealed Credo Cube ${ }^{\mathrm{TM}}$ as sub-depot of the transfusion service of the University Medicine Greifswald. If the seal is broken the blood products are issued to the HEMS operator and cannot be re-integrated into the in-hospital blood bank.

Responsibility for the transfusion process is with the HEMS operator, the DRF Luftrettung. They have set up a hospital-like transfusion system with board, quality management, and physician in charge, which enables the company to use blood products according to German regulation. Any other agreement between the blood service and the HEMS operator, which includes transfer of patient data after transfusion from the helicopter team to the blood bank requires appropriate contracts according to the local regulations of patient data protection.

\section{Discussion}

The Credo Cube ${ }^{\mathrm{TM}}$ allows storage of blood components at $4^{\circ} \mathrm{C} \pm 2^{\circ} \mathrm{C}$ for up to $36 \mathrm{~h}$ even at ambient temperatures of $35^{\circ} \mathrm{C}$. RBC and tFFP quality were maintained after 3 days of HEMS. The helicopter is equipped with blood products in Greifswald since June 2019 and up to now none of the returned products showed obvious quality impairment. Changes in clotting factor activities did not differ from aliquots of the same product stored in the blood bank at $2-6^{\circ} \mathrm{C}$ after thawing and were in the same range as described previously for the storage of thawed plasma at $2-6^{\circ} \mathrm{C}$ for up to 7 days [25].

Critical for planning of the logistic sequence is the appropriate preparation of the cooling tiles of the Credo Cube $^{\mathrm{TM}}$. After the deep freeze period at $\leq-18^{\circ} \mathrm{C}$ the tiles have to be stored at $2-6^{\circ} \mathrm{C}$ for at least $12 \mathrm{~h}$. Otherwise the tiles might be too cold for the blood products and potentially harm red cells. If the tiles are prepared at $4^{\circ} \mathrm{C}$ only, the period during which temperature is maintained below $6^{\circ} \mathrm{C}$ decreases rapidly (data not shown).

At least two blood transport containers and three sets of cooling tiles are required to ensure a 24-h supply including the possibility to rapidly reload the Credo Cube ${ }^{\mathrm{TM}}$ in case of transfusion. In line with prior reports, which used other transport boxes [26], we observed a minor increase of potassium concentration in red cells, which however, maintained within the RBC specification.

After thawing of FFP the most sensitive clotting factor is factor VIII for which the most pronounced loss of activity occurred within the first $24 \mathrm{~h}$, but mean activity was maintained higher than 50\%. After 3 days HEMS operation (5 days after thawing) factor VIII further decreased to a mean level of $47 \%$. This loss of FVIII activity is in the expected range: Buchta et al. described a factor VIII decrease to $0.53(0.51-0.54 \mathrm{U} / \mathrm{mL})$ [27], and von Heymann described a decrease of the factor VIII activity by $43 \%$ after storage of thawed plasma at $4^{\circ} \mathrm{C}$ for 6 days [28]. In general, the helicopter transport did not affect clotting factor activities any different compared to aliquots of the same plasma stored at the blood bank under regular conditions. We have previously shown that the loss of procoagulatory activities of clotting factor VIII and IX in plasma stored at $4 \pm 2^{\circ} \mathrm{C}$ did not impair its thrombin generation potential as also anticoagulatory clotting factors are decreased [29]. In this regard the present study also observed a parallel decrease in factor VIII and protein $\mathrm{S}$ activities. This adds relevant information. We systematically validated tFFP using plasmapheresis plasma [25], while we used source plasma for the current study. Source plasma might have less well preserved clotting factors compared to apheresis plasma due to longer storage of whole blood before fractionation. It is therefore encouraging that we found no quality impairment of thawed tFFP obtained from whole blood donations in the current analyses.

As discussed before in detail [25], in case of massive transfusion the follow-up blood products will be freshly thawed plasma, maintaining clotting factor levels in the patient. 
An alternative to thawed plasma is lyophilized plasma, which we also use in the Credo Cube ${ }^{\mathrm{TM}}$, but the size of the plasma bottles and the water bags needed for reconstitution only allow transport of two lyophilized plasma units together with two RBCs. Further disadvantage is that manipulation and time for reconstitution is needed to get a ready-to-transfuse product.

The decision to establish a blood inventory on HEMS has to be made in regard to the HEMS operating area, local hospital density, the risk of major trauma e.g. by difficult traffic conditions and the associated obstacles for ground emergency medical service. Mecklenburg-Vorpommern is an area with large distances between hospitals and large distances between blood suppliers and hospital blood banks. The possibility to start transfusions within $30 \mathrm{~min}$ after trauma helps to bridge the time for large distance transport to the next hospital/trauma center.

While our study shows the feasibility to carry an emergency blood depot on the helicopter, we did not perform any outcome studies. Up to now eight patients received blood transfusion during HEMS operation in Greifswald. We did not observe any major deviations or major adverse events, but the number of patients is too small to draw any meaningful conclusions on clinical efficacy. This will require to combine the results of all patients receiving prehospital transfusions on the helicopter in Germany during the last 2 years.

\section{Conclusion}

The present study shows the feasibility of supplying the helicopter emergency medical service with RBCs and plasma. Helicopter transport has no negative impact on blood product quality. The logistic challenges require close collaboration between the helicopter team and the blood transfusion service.

\section{Acknowledgement}

The authors thank Yvonne Scott (The Newcastle upon Tyne hospitals NHS Foundation Trust, Newcastle upon Tyne, United Kingdom) for providing her experience in implementing blood on a helicopter. We thank Yasmin Liedtka for technical assistance in the processes of cooling tile activation, packing of the Credo Cube $^{\mathrm{TM}}$ and temperature monitoring. We thank Antje Westphal for support in data management and analysis.

\section{Statement of Ethics}

The prospective observation of the patients who received prehospital blood transfusion from the HEMS blood container is approved by our local ethical committee (reg. No. BB020/20). The data presented for validation of storage and transport conditions monitoring the blood product quality by HEMS transport were collected based on "Arzneimittel- und Wirkstoffherstellungsverordnung - AMWHV” $\$ 7$ by German legislature.

\section{Conflict of Interest Statement}

M.B. and K.-C.T. are members of the scientific working group of the DRF Luftrettung. M.R., F.R., J.B. are employees of the DRF Luftrettung. K.S. received research funding from Immucor, traveling support from SOBI and consultant fees from Aspen. A.G. received research funding from Ergomed, Boehringer Ingelheim, Rovi, Sagent, Macopharma, Portola, Biokit, Blau Farmaceutics, Prosensa/Biomarin, DRK-BSD NSTOB, DRK-BSD Baden-Württemberg/Hessen, travel support, speakers and consulting fees from Roche, GTH e.V., Sanofi-Aventis, Macopharma, Chromatec, Instrumentation Laboratory, Bayer Vital and Aspen. B.H., G.J., M.H., T.W., K.H. declare no conflict of interest.

\section{Funding Sources}

The study was funded by the DRF Stiftung Luftrettung gemeinnützige AG, Filderstadt, Germany.

\section{Author Contributions}

M.B., G.J., K.-C.T., K.S., and A.G. designed the validation plan. M.B. organized the logistics of the laboratory measurements. G.J., K.-C.T., K.H. organized the transport logistics between the hospital blood bank and helicopter port. M.R., F.R., J.B. provided the storage containers and developed the quality management structure and policies for hemotherapy under HEMS conditions. M.B., M.H., T.W. performed RBC and tFFP quality assessment. M.B. and K.S. analyzed the results. M.B., K.-C.T., B.H., K.S., and A.G. wrote the manuscript. All authors finally approved the submitted version of manuscript.

\section{References}

1 Sobrino J, Shafi S. Timing and causes of death after injuries. Proc (Bayl Univ Med Cent). 2013;26(2):120-3.

2 Vulliamy P, Thaventhiran AJ, Davenport RA. What's new for trauma haemorrhage management? Br J Hosp Med (Lond). 2019;80(5): 268-73.

3 Kauvar DS, Lefering R, Wade CE. Impact of hemorrhage on trauma outcome: an overview of epidemiology, clinical presentations, and therapeutic considerations. J Trauma. 2006; 60(6 Suppl 1):S3-11.

4 Holcomb JB, del Junco DJ, Fox EE, Wade CE, Cohen MJ, Schreiber MA, et al. The prospective, observational, multicenter, major trauma transfusion (PROMMTT) study: comparative effectiveness of a time-varying treatment with competing risks. JAMA Surg. 2013; 148(2):127-36.

5 Kotwal RS, Scott LLF, Janak JC, Tarpey BW, Howard JT, Mazuchowski EL, et al. The effect of prehospital transport time, injury severity, and blood transfusion on survival of US military casualties in Iraq. J Trauma Acute Care Surg. 2018;85(1S Suppl 2):S112-21. 
6 Den Hartog D, Romeo J, Ringburg AN, Verhofstad MH, Van Lieshout EM. Survival benefit of physician-staffed Helicopter Emergency Medical Services (HEMS) assistance for severely injured patients. Injury. 2015;46(7): 1281-6.

7 Peters JH, Smulders PSH, Moors XRJ, Bouman SJM, Meijs CMEM, Hoogerwerf N, et al. Are on-scene blood transfusions by a helicopter emergency medical service useful and safe? A multicentre case-control study. Eur J Emerg Med. 2019;26(2):128-32.

8 Moore HB, Moore EE, Chapman MP McVaney K, Bryskiewicz G, Blechar R, et al. Plasma-first resuscitation to treat haemorrhagic shock during emergency ground transportation in an urban area: a randomised trial. Lancet. 2018;392(10144):283-91.

9 Barkana Y, Stein M, Maor R, Lynn M, Eldad A. Prehospital blood transfusion in prolonged evacuation. J Trauma. 1999;46(1):176-80.

10 Higgins GL, 3rd, Baumann MR, Kendall KM, Watts MA, Strout TD. Red blood cell transfusion: experience in a rural aeromedical transport service. Prehosp Disaster Med. 2012; 27(3):231-4.

11 Sumida MP, Quinn K, Lewis PL, Jones Y, Barker DE, Ciraulo DL, et al. Prehospital blood transfusion versus crystalloid alone in the air medical transport of trauma patients. Air Med J. 2000;19(4):140-3.

12 Brown JB, Sperry JL, Fombona A, Billiar TR, Peitzman AB, Guyette FX. Pre-trauma center red blood cell transfusion is associated with improved early outcomes in air medical trauma patients. J Am Coll Surg. 2015;220(5): 797-808.

13 Holcomb JB, Swartz MD, DeSantis SM, Greene TJ, Fox EE, Stein DM, et al. Multicenter observational prehospital resuscitation on helicopter study. J Trauma Acute Care Surg. 2017;83(1 Suppl 1):S83-91.

14 Holcomb JB, Donathan DP, Cotton BA, Del Junco DJ, Brown G, Wenckstern TV, et al Prehospital Transfusion of Plasma and Red Blood Cells in Trauma Patients. Prehosp Emerg Care. 2015;19(1):1-9.
15 Wheeler R, von Recklinghausen FM, Brozen R. Blood administration in helicopter emergency medical services patients associated with hypothermia. Air Med J. 2013;32(1):4751.

16 Sivakumar S. Helicopter landing gear vibration analysis using Lagrange method. 2018; 21:96-101.

17 Richtlinie zur Gewinnung von Blut und Blutbestandteilen und zur Anwendung von Blutprodukten (Richtlinie Hämotherapie) [Internet]. Bundesärztekammer, Paul-Ehrlich-Institut/Deutscher Ärzteverlag; 2017 [cited 2021 Jun 2]. Available from: https://www. bundesaerztekammer.de/fileadmin/user_upload/downloads/pdf-Ordner/MuE/Richtlinie_Haemotherapie_E_A_2019.pdf.

18 Liu HC, Zhang LJ, Ping YJ, Wang L. Failure mode and effects analysis for proactive healthcare risk evaluation: A systematic literature review. J Eval Clin Pract. 2020;26(4): 1320-37.

19 Stamatis DH. Failure Mode and Effect Analysis: FMEA from Theory to Execution [Internet]: ASQ Quality Press; 2003. Available from: https: //books.google.de/books?id= TTxI8jbTkVwC.

20 Committee for Human Medicinal Products. ICH (International Council for Harmonisation) guideline Q9 on quality risk management [Internet]. European Medical Agency 2015 [cited 2021 Jun 20]. Available from: https: //www.ema.europa.eu/en/documents/ scientific-guideline/international-conference-harmonisation-technical-requirements-registration-pharmaceuticals-humanuse_en-3.pdf.

21 Dunbar NM, Yazer MH; Biomedical Excellence for Safer Transfusion Collaborative. A possible new paradigm? A survey-based assessment of the use of thawed group A plasma for trauma resuscitation in the United States. Transfusion. 2016;56(1):125-9.
22 Dunbar NM, Yazer MH; Biomedical Excellence for Safer Transfusion (BEST) Collaborative and the STAT Study Investigators. Safety of the use of group A plasma in trauma: the STAT study. Transfusion. 2017;57(8):187984.

23 Selleng K. Der Blutungsnotfall - Versorgungskonzepte für Patienten mit unbekannter Blutgruppe. Transfusionsmedizin - Immunhämatologie · Hämotherapie · Transplantationsimmunologie - Zelltherapie. 2020;10(03):151-8.

24 Gesetz zur Regelung des Transfusionswesens (Transfusionsgesetz - TFG) [Internet]. Bundesministerium der Justiz und für Verbraucherschutz, Bundesamt für Justiz; 1998 [cited 2021 Jun 20]. Available from: https:// www.gesetze-im-internet.de/tfg/index.html.

25 Thiele T, Kellner S, Hron G, Wasner C, Nauck M, Zimmermann K, et al. Storage of thawed plasma for a liquid plasma bank: impact of temperature and methylene blue pathogen inactivation. Transfusion. 2012;52(3):529-36.

26 Otani T, Oki K, Akino M, Tamura S, Naito Y, Homma C, et al. Effects of helicopter transport on red blood cell components. Blood Transfus. 2012;10(1):78-86.

27 Buchta C, Felfernig M, Höcker P, Macher M, Körmöczi GF, Quehenberger P, et al. Stability of coagulation factors in thawed, solvent/detergent-treated plasma during storage at 4 degrees C for 6 days. Vox Sang. 2004;87(3):182-6.

28 von Heymann C, Keller MK, Spies C, Schuster M, Meinck K, Sander M, et al. Activity of clotting factors in fresh-frozen plasma during storage at 4 degrees $\mathrm{C}$ over 6 days. Transfusion. 2009;49(5):913-20.

29 Thiele T, Hron G, Kellner S, Wasner C, Westphal A, Warkentin TE, et al. Thrombin generation, ProC $((\mathrm{R}))$ Global, prothrombin time and activated partial thromboplastin time in thawed plasma stored for seven days and after methylene blue/light pathogen inactivation. Blood Transfus. 2016;14(1):66-72. 